\title{
Pemetaan Total Fertility Rate (TFR) di Jawa Timur Menggunakan Pendekatan Regresi Logistik Biner dengan Efek Interaksi
}

\author{
Nisa Andini dan Vita Ratnasari \\ Departemen Statistika, FMKSD, Institut Teknologi Sepuluh Nopember (ITS) \\ e-mail:vitaratna70@gmail.com
}

\begin{abstract}
Abstrak-Total Fertility Rate (TFR) atau Angka Fertilitas Total merupakan salah satu indikator untuk membandingkan keberhasilan antar wilayah dalam melaksanakan pembangunan sosial ekonomi, seperti menunjukkan tingkat keberhasilan program Keluarga Berencana (KB). Pada tahun 2015, TFR Jawa Timur adalah 2,03 anak dimana angka tersebut berada di bawah TFR nasional. Perwakilan BKKBN Jawa Timur menargetkan Angka Fertilitas Total kabupaten/kota berada di bawah 2,03. Kabupaten/kota dibagi menjadi dua kategori, dikatakan belum mencapai target apabila TFR lebih dari 2,03 dan sudah mencapai target apabilai TFR kurang dari 2,03. Data menunjukkan adanya kesenjangan Angka Fertilitas Total antar kabupaten dan kota di Jawa Timur dimana masih terdapat daerah yang memiliki Angka Fertilitas Total tinggi di atas 2,03. Hasil pemodelan menunjukkan bahwa persentase unmet need, rata-rata lama sekolah perempuan, informed consent, PDRB Perkapita, persentase pasangan usia subur, serta interaksi antara informed consent dan PDRB perkapita berpengaruh terhadap Angka fertilitas total pada tingkat kepercayaan $90 \%$. Ketepatan klasifikasi yang diperoleh sebesar 92,1\% dimana masih ada tiga daerah yang misklasifikasi, yaitu Kabupaten Jember, Kabupaten Blitar, dan Kabupaten Pacitan.
\end{abstract}

Kata Kunci-Angka Fertilitas Total, Interaksi, Klasifikasi, Moderator, Regresi Logistik.

\section{PENDAHULUAN}

$\mathbf{J}^{\mathrm{s}}$ UMLAH penduduk di Jawa Timur diprediksi semakin bertambah dari tahun ke tahun. Pertambahan penduduk dapat menjadi modal pembangunan karena terdapat angkatan kerja sesuai perkembangan penduduk tersebut. Secara terus menerus, pertambahan penduduk terjadi karena jumlah bayi yang lahir semakin bertambah atau tingginya fertilitas. Tingginya fertilitas jika tidak dibarengi dengan peningkatan sumber daya manusia yang berkualitas dapat menimbulkan masalah-masalah sosial di masyarakat. Tingkat fertililitas suatu daerah diukur dengan Total Fertility Rate (TFR) atau Angka Fertilitas Total.

Angka Fertilitas Total di Jawa Timur mengalami penurunan yang signifikan sejak 1971 hingga tahun 2015. Pada tahun 2015, Jawa Timur menjadi salah satu provinsi yang telah berhasil mencapai target BKKBN dengan TFR sebesar 2,032. Namun, target ini belum bisa dicapai oleh semua kabupaten dan kota di Jawa Timur. Hal ini dikarenakan masih adanya kesenjangan Angka Fertilitas Total antar kabupaten dan kota di Jawa Timur dimana terdapat daerah yang memiliki Angka Fertilitas Total tinggi di atas 2,03. Adanya kesenjangan menunjukkan masih belum ratanya pembangunan Keluarga Berencana $(\mathrm{KB})$ di wilayah tersebut dan pertumbuhan ekonominya belum berkualitas.

Penelitian mengenai Angka Fertilitas Total telah dilakukan oleh Ladimar mengenai analisis tingkat fertilitas di Jawa Timur menggunakan Regresi Data Panel dengan pendekatan model tetap. Hasilnya, partisipasi perempuan dalam pasar kerja, perempuan sedang menggunakan alat $\mathrm{KB}$, persentase rumah tangga yang memiliki pengeluaran perkapita di atas 500 ribu perbulan dan pengangguran perempuan berpengaruh signifikan terhadap tingkat fertilitas di Kabupaten/kota Provinsi Jawa Timur [1].

Adanya interaksi antar variabel prediktor dalam pemodelan memungkinkan salah-satunya merupakan variabel antara (moderator) yang menghubungkan variabel lain untuk mempengaruhi respon. Salah satu metode yang dapat digunakan untuk menentukan interaksi antar variabel adalah Moderated Multiple Regression. Penelitian menggunakan interaksi variabel telah dilakukan oleh Isnaini menggunakan metode Probit Biner [2]. Penelitian tersebut memberikan hasil bahwa adanya efek interaksi berkontribusi dalam meningkatkan akurasi model menjadi 82,692\%. Dalam penelitian Li, Weng, Shao, \& Guo [3], pemodelan sering memberikan akurasi prediksi yang rendah karena efek interaksi dan efek tersembunyi dari faktor yang mempengaruhi. Untuk itu, perlu diidentifikasi interaksi antar variabel.

Penelitian ini bertujuan untuk mengetahui karakteristik fertilitas, faktor-faktor yang mempengearuhi fertilitas, dan pemetaan TFR di Jawa Timur. Hasil penelitian ini diharapkan dapat memberi informasi dan pertimbangan dalam menentukan kebijakan bagi BKKBN Provinsi Jawa Timur dalam upaya menekan fertilitas.

\section{TINJAUAN PUSTAKA}

\section{A. Multikolinearitas}

Multikolinearitas merupakan keadaan terjadinya kolerasi linear yang tinggi di antara variabel-variabel prediktor $X_{1}, X_{2}$, $\ldots, X_{p}$. Multikolinearitas menyebabkan variansi estimasi menjadi besar, interval kepercayaan menjadi lebar, pengujian signifikansi menjadi tidak signifikan, serta koefisien determinasi $\mathrm{R}^{2}$ tinggi namun sedikit variabel prediktor yang signifikan. Metode yang dapat digunakan untuk mendeteksi multikolinearitas adalah Variance Inflation Factor (VIF). Apabila nilai VIF lebih dari 10, maka dapat diindikasikan terdapat kasus multikolinearitas [4]. 


\section{B. Regresi Logistik}

Regresi logistik merupakan salah satu metode yang digunakan untuk menggambarkan hubungan antara variabel respon $(Y)$ berskala kategorik dengan satu atau beberapa variabel prediktor $(X)$. Variabel $Y$ mengikuti distribusi Binomial. Apabila variabel prediktor ada sebanyak $p$ variabel, maka model regresi Logistik dapat dituliskan dalam bentuk logit, yaitu fungsi link dari regresi Logistik.

$$
\operatorname{logit}\left[\pi_{i}\left(x_{i}\right)\right]=\log \left[\frac{\pi_{i}\left(x_{i}\right)}{1-\pi_{i}\left(x_{i}\right)}\right]=\beta_{0}+\beta_{1} x_{i 1}+\mathrm{L}+\beta_{p} x_{\text {ip }}
$$

Berdasarkan fungsi logit di atas, $x_{i j}$ adalah nilai variabel respon ke- $j$ pada observasi ke- $i$ sedangkan $\beta_{\tilde{f}}$ adalah koefisien regresi variabel prediktor ke-j. Model berikut ini menghubungkan probabilitas terjadinya kejadian dengan variabel prediktor [5].

$$
\begin{gathered}
\pi_{i}\left(\mathbf{x}_{i}\right)=\frac{\exp \left(\mathbf{x}_{\mathbf{i}} \boldsymbol{\beta}\right)}{1-\exp \left(\mathbf{x}_{\mathbf{i}} \boldsymbol{\beta}\right)} \\
\mathbf{x}_{\mathbf{i}} \boldsymbol{\beta}=\beta_{0}+\beta_{1} x_{i 1}+\beta_{2} x_{i 2}+\mathrm{L}+\beta_{j} x_{i j}+\mathrm{L}+\beta_{p} x_{i p}
\end{gathered}
$$

$\beta_{0}$ merupakan konstanta sedangkan $\beta_{j}$ merupakan koefisien regresi pada variabel prediktor ke-j.

Estimator $\beta$ Maximum Likelihood diperoleh dengan memaksimumkan logaritma dari fungsi likelihood.

$$
\begin{gathered}
L(\mathbf{X}, \boldsymbol{\beta})=\prod_{i=1}^{n}\left[\pi_{i}\left(\mathbf{x}_{i}\right)\right]^{y_{i}}\left[1-\pi_{i}\left(\mathbf{x}_{i}\right)\right]^{1-y_{i}} \\
\ln L(\mathbf{X}, \boldsymbol{\beta})=\sum_{i=1}^{n}\left[y_{i}\left(\mathbf{x}_{i} \boldsymbol{\beta}\right)-\ln \left(1+\exp \left(\mathbf{x}_{i} \boldsymbol{\beta}\right)\right)\right] \\
\hat{\boldsymbol{\beta}}=\left(\mathbf{X}^{T} \mathbf{W} \mathbf{X}\right)^{-1} \mathbf{X}^{T} \mathbf{W} \mathbf{z}
\end{gathered}
$$

Nilai $\mathbf{z}$ merupakan vektor yang berukuran $n \times 1$ dengan:

$$
\begin{array}{r}
z_{i}=\operatorname{Logit}\left[\hat{\pi}_{i}\left(\mathbf{x}_{i}\right)\right]+\frac{y_{i}-\hat{\pi}_{i}\left(\mathbf{x}_{i}\right)}{\hat{\pi}_{i}\left(\mathbf{x}_{i}\right)\left[1-\hat{\pi}_{i}\left(\mathbf{x}_{i}\right)\right]} \\
\operatorname{Var}(\hat{\boldsymbol{\beta}})=\left(\mathbf{X}^{T} \operatorname{diag}\left[\hat{\pi}_{i}\left(1-\hat{\pi}_{i}\right)\right] \mathbf{x}\right)^{-1}
\end{array}
$$

\section{Pengujian Signifikansi Parameter}

Pengujian signifikansi parameter secara serentak dilakukan dengan menggunakan Likelihood Ratio Test, dimana hipotesis yang digunakan adalah:

$\mathrm{H}_{0}: \beta_{1}=\beta_{2}=\ldots=\beta_{P}=0$

$\mathrm{H}_{1}: \beta_{\mathrm{j}} \neq 0$, dimana $j=1,2, \ldots, p$

Statistik uji Likelihood Ratio Test yang digunakan adalah sebagai berikut:

$$
\begin{gathered}
G=-2 \ln \left[\frac{\left(\frac{n_{0}}{n}\right)^{n_{0}}\left(\frac{n_{1}}{n}\right)^{n_{i}}}{\prod_{i=1}^{n}\left(\hat{\pi}_{i}\right)^{y_{i}}\left(1-\hat{\pi}_{i}\right)^{1-y_{i}}}\right] \\
G=-2 \log \left(\frac{L_{0}}{L_{1}}\right)=-2\left[\ln \left(L_{0}\right)-\left(L_{1}\right)\right]
\end{gathered}
$$

Nilai G mengikuti distibusi Chi-square dengan derajat bebas df sebesar $p$. Jika $G \geq \chi_{p, \alpha}^{2}$, maka diputuskan untuk menolak $\mathrm{H}_{0}$ yang menunjukkan minimal terdapat satu variabel prediktor berpengaruh signifikan terhadap variabel respon [6].
Selanjutnya, dapat dilakukan uji signifikansi parameter dengan pengujian parsial untuk mengetahui variabel-variabel prediktor mana yang signifikan terhadap variabel respon Pengujian signifikansi parameter dilakukan menggunakan Wald test dengan hipotesis sebagai berikut.

$\mathrm{H}_{0}: \beta_{\mathrm{j}}=0$

$\mathrm{H}_{1}: \beta_{\mathrm{j}} \neq 0$, dimana $j=1,2, \ldots, p$

Statistik uji Wald test dihitung dengan rumus sebagai berikut:

$$
W=\left[\frac{\hat{\beta}_{j}}{S E\left(\hat{\beta}_{j}\right)}\right]^{2}
$$

dimana: $\operatorname{SE}\left(\hat{\beta}_{j}\right)=\sqrt{\operatorname{Var}\left(\hat{\beta}_{j}\right)}$

Hasil pengujian diputuskan tolak $H_{0}$ apabila nilai $W^{2}>\chi_{v, \alpha}^{2}$ atau $p$-value kurang dari $\alpha$. Artinya, variabel ke- $j$ berpengaruh signifikan terhadap pembentukan model. $\alpha$ merupakan taraf signifikansi yang digunakan, yakni 5\% [6].

\section{Uji Kesesuaian Model}

Goodness of fit test atau uji kesesuaian model merupakan pengujian yang digunakan untuk mengetahui apakah terdapat perbedaan antara hasil observasi dengan kemungkinan hasil prediksi model. Hipotesis yang digunakan adalah sebagai berikut:

$\mathrm{H}_{0}$ : model telah sesuai (tidak ada perbedaan antara hasil observasi dengan hasil prediksi)

$\mathrm{H}_{1}$ : model belum sesuai (ada perbedaan antara hasil observasi dengan hasil prediksi)

Statistik uji Deviasi (D) digunakan sebagai pendekatan untuk menilai goodness of fit.

$$
D=-2 \sum_{i=1}^{n}\left[y_{i} \ln \left(\frac{\hat{\pi}_{i}}{y_{i}}\right)+\left(1-y_{i}\right) \ln \left(\frac{1-\hat{\pi}_{i}}{1-y_{i}}\right)\right]
$$

Keputusan menolak hipotesis null $\left(\mathrm{H}_{0}\right)$ jika $D>\chi_{n-p-1, \alpha}$ dengan $\alpha$ merupakan taraf signifikansi sebesar $10 \%[6]$.

\section{E. Interaksi Variabel}

Pemodelan Regresi Logistik memungkinkan terdapat efek interaksi antar variabel prediktor. Interaksi antar variabel dibuat sebagai bentuk aritmatika dari pasangan variabel efek utama [6]. Adanya interaksi variabel dapat terjadi akibat variabel moderator. Kehadiran variabel moderator dapat mengubah hubungan awal antara variabel prediktor dengan respon [7].

\section{F. Moderated Multiple Regression}

Moderated Multiple Regression atau uji interaksi adalah aplikasi dari regresi linier berganda, dimana dalam persamaaanya mengandung unsur interaksi. Jika terdapat variabel respon $Y$ dengan variabel prediktor pertama adalah $X$ dan variabel prediktor kedua yang dianggap sebagai variabel moderator adalah $Z$.

$$
Y=\beta_{0}+\beta_{1} X+\beta_{2} Z+\varepsilon
$$

Kemudian diberikan persamaan kedua, yaitu persamaan yang mengandung variabel baru berupa hasil perkalian antara variabel $\mathrm{X}$ dan variabel $\mathrm{Z}$ [8]. 


$$
Y=\beta_{0}+\beta_{1} X+\beta_{2} Z+\beta_{3} X * Z+\varepsilon
$$

Untuk menguji signifikansi efek variabel moderator secara statistik, dapat dilakukan dengan uji-F dan uji-t [9]. Pada persamaan (12), jika koefisien $\beta_{2}$ tidak signifikan namun koefisien $\beta_{3}$ signifikan, maka jenis moderasinya adalah moderasi murni. Jika koefisien $\beta_{2}$ dan $\beta_{3}$, maka jenis moderasinya adalah moderasi semu. Jika $\beta_{2}$ signifikan namun $\beta_{3}$ tidak signifikan, maka jenis moderasinya adalah prediktor moderasi. Sedangkan jika keduanya tidak signifikan maka variabel interaksi $X$ dengan $Z$ bukan sebagai variabel moderator.

\section{G. Evaluasi Ketepatan Klasifikasi}

Salah satu cara yang digunakan untuk mengevaluasi ketepatan klasifikasi di antaranya melalui perhitungan Apparent Error Rate (APER), total accuracy rate (1-APER), sensitivity, dan specificity. Menurut Johnson dan Wichern [10], APER merupakan proporsi observasi yang diprediksi secara tidak benar (ukuran kesalahan klasifikasi total). Total accuracy rate merupakan proporsi observasi yang diprediksi secara benar (ukuran ketepatan klasifikasi total). Specificity mengukur proporsi yang benar-benar negatif, yaitu proporsi dari kelas 0 yang teridentifikasi secara benar. Sensitivity mengukur proporsi yang benar-benar positif, yaitu proporsi dari kelas 1 yang teridentifikasi secara benar [11].

\section{H. Konsep Fertilitas}

Istilah fertilitas sama dengan kelahiran hidup (live birth), yaitu terlepasnya bayi dari rahim seorang perempuan denga nada tanda-tanda kehidupan, misalnya berteriak, bernafas, jantung berdenyut, dan sebagainya [10]. Dalam pengertian lain, fertilitas adalah tingkat kelahiran riil dari seorang wanita selama masa reproduksi. Di Indonesia, masa reproduksi dimulai sejak usia 15 tahun dan akan berhenti pada usia 49 tahun [11].

\section{Angka Fertilitas Total}

Untuk menilai kondisi kesehatan masyarakat dibutuhkan suatu yang dapat digunakan sebagai indikator untuk menilai kondisi kesehatan masyarakat. Salah satunya dengan menggunakan Angka Fertilitas Total. Angka Fertilitas Total atau Total Fertility Rate (TFR) merupakan rata-rata anak yang dilahirkan seorang wanita selama masa usia suburnya [12].

\section{J. Faktor-Faktor yang Mempengaruhi Angka Fertilitas Total}

Faktor-faktor yang mempengaruhi tinggi rendahnya penduduk dapat dibagi menjadi dua, yaitu faktor demografi dan faktor non demografi. Faktor demografi di antaranya adalah stuktur umur, struktur perkawinan, umur kawin pertama, paritas, disrupsi perkawinan, dan proporsi yang kawin. Sedangkan faktor non demografi antara lain keadaan ekonomi penduduk, tingkat pendidikan, perbaikan status perempuan, urbanisasi, dan industrialisasi. Variabel-variabel di atas dapat berpengaruh secara langsung terhadap fertilitas, ada juga yang tidak langsung [10].

\section{METODOLOGI PENELITIAN}

\section{A. Sumber Data}

Jenis data yang digunakan adalah data sekunder yang diperoleh melalui perwakilan BKKBN Provinsi Jawa Timur, Publikasi BPS, dan Jawa Timur dalam Angka 2016. Data yang digunakan berupa Angka Fertilitas Total atau Total Fertility Rate (TFR) beserta tujuh faktor yang diduga mempengaruhi TFR dari 29 kabupaten dan sembilan kota di Jawa Timur tahun 2015.

\section{B. Variabel Penelitian}

Variabel respon, yaitu Angka Fertilitas Total (Y) dikategorikan menjadi dua kategori, yaitu $y=1$ jika TFR sesuai target $\mathrm{BKKBN} \leq 2,03$ dan $y=0$ apabila TFR $>2,03$. Berikut ini adalah variabel respon dan variabel prediktor yang digunakan dalam penelitian ini.

Tabel 1.

Variabel Penelitian

\begin{tabular}{ll}
\hline \hline Variabel & Skala \\
\hline Angka Fertilitas Total $(\mathrm{Y})$ & Kategorik \\
Contraceptive Prevalence Rate $\left(\mathrm{X}_{1}\right)$ & Rasio \\
Persentase Unmet need $\mathrm{KB}\left(\mathrm{X}_{2}\right)$ & Rasio \\
Usia perkawinan pertama $\left(\mathrm{X}_{3}\right)$ & Rasio \\
Angka Kematian Bayi $\left(\mathrm{X}_{4}\right)$ & Rasio \\
Rata-rata lama sekolah perempuan $\left(\mathrm{X}_{5}\right)$ & Rasio \\
Pemberian Informed Consent $\left(\mathrm{X}_{6}\right)$ & Rasio \\
PDRB Perkapita $\left(\mathrm{X}_{7}\right)$ & Rasio \\
Persentase PUS $\left(\mathrm{X}_{8}\right)$ & Rasio \\
\hline \hline
\end{tabular}

C. Langkah Analisis

Berikut merupakan langkah-langkah yang dilakukan untuk mencapai tujuan penelitian.

1. Mendeskripsikan data Angka fertilitas total (Y) dan faktor-faktor yang diduga mempengaruhinya.

2. Memeriksa asumsi multikolinearitas.

3. Melakukan pemodelan Regresi Logistik tanpa interaksi.

4. Membentuk interaksi variabel menggunakan Moderated Multiple Regression.

5. Melakukan pemodelan Regresi Logistik dengan efek interaksi.

6. Memilih model terbaik menggunakan seleksi Backward.

7. Menghitung nilai odds ratio setiap variabel yang signifikan.

8. Menghitung ketepatan klasifikasi yang diukur dengan nilai akurasi, sensitivity, dan specificity.

9. Memetakan Angka fertilitas total data aktual dan hasil pemodelan Regresi Logistik dengan efek interaksi.

\section{ANALISIS DAN PEMBAHASAN}

\section{A. Eksplorasi Data Penelitian}

Total Fertility Rate (TFR) atau Angka fertilitas total merupakan perhitungan kelahiran yang digunakan untuk menggambarkan rata-rata jumlah anak yang dilahirkan oleh wanita usia 15 sampai 49 tahun. BKKBN menginginkan Angka fertilitas kabupaten/kota di Jawa Timur berada di bawah TFR Jawa Timur, yaitu 2.03. Untuk itu, kabupaten/kota yang memiliki TFR di bawah 2.03 dapat dikatakan telah mencapai target dan di atas 2.03 berarti belum mencapai target. 


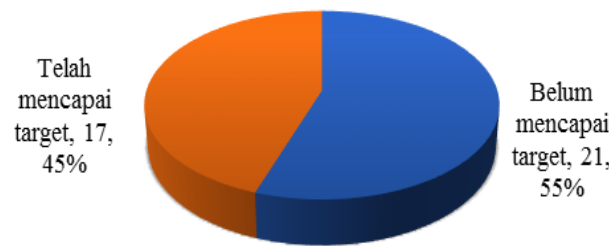

Gambar 1. Persentase Ketercapaian Target Total Fertility Rate (TFR).

persentase kabupaten/kota yang telah mencapai target TFR masih lebih kecil dibandingkan persentase kabupaten/kota yang belum mencapai target. Dari 38 kabupaten/kota, hanya $45 \%$, yaitu 12 kabupaten dan lima kota yang telah mencapai target. Angka fertilitas total terkecil dicapai oleh Kabupaten Sumenep dengan TFR sebesar 1,52 dan yang tertinggi adalah Kabupaten Sampang dengan TFR 2,45. Hasil ini juga dapat menunjukkan program keluarga berencana belum berjalan maksimal di Kabupaten Sampang.

Hubungan antar variabel dapat digambarkan menggunakan analisis kuadran, misalnya hubungan antara angka prevalensi pemakaian KB (CPR) dengan Angka fertilitas total (TFR).

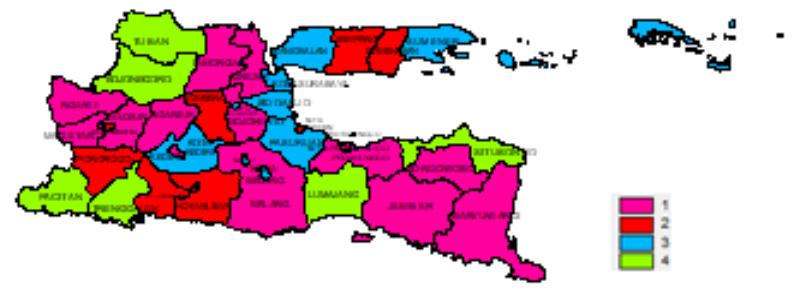

Gambar 2. Kuadran CPR dan TFR dalam Peta Jawa Timur.

Kuadran I menggambarkan kondisi dimana CPR dan TFR yang tinggi di suatu wilayah, yakni CPR di atas $65,3 \%$ dan TFR di atas 2,03. Penyebabnya bisa berasal dari pernikahan usia muda yang tinggi, peserta yang ikut KB telah memiliki anak yang sudah banyak, peserta KB berusia tua, atau peserta KB sudah tidak efektif menggunakan KB, seperti alat/obatnya tidak efektif atau mudah dropout. Wilayah yang terletak di kuadran I ada 13 kabupaten dan satu kota, yaitu kabupaten Kediri, Malang, Jember, Banyuwangi, Bondowoso, Probolinggo, Mojokerto, Nganjuk, Madiun, Magetan, Ngawi, Lamongan, Gresik, dan Kota Probolinggo.

Kuadran II mengambarkan kondisi wilayah yang memiliki TFR tinggi dan CPR rendah. Wilayah-wilayah yang masuk pada kuadran ini memerlukan perbaikan dan perhatian serius dari program KB. Hal ini dikarenakan masih rendahnya kesertaan ber-KB para Pasangan Usia Subur (PUS) sehingga terjadi pengingkatan TFR. Wilayah yang berada dalam kuadran II adalah Kabupaten Ponorogo, Tulungagung, Blitar, Jombang, Sampang, Pamekasan, Kota Blitar, Pasuruan, dan Madiun.

Kuadran III ditempati oleh wilayah yang memiliki TFR dan CPR yang sama-sama rendah. Rendahnya fertilitas pada wilayah yang masuk pada kuadran III dapat disebabkan oleh faktor lain di luar program Keluarga Berencana (KB), misalnya banyak penduduk yang menikah di usia dewasa, tingkat pendidikan yang tinggi, pendapatan tinggi, banyak penduduk yang bekerja dan sebagainya. Kuadran III diisi oleh Kabupaten Pasuruan, Sidoarjo, Sumenep, Bangkalan, Kota Kediri, Malang, Mojokerto, Surabaya, dan Batu.

Kuadran IV diisi oleh daerah-daerah yang memiliki TFR rendah dan CPR tinggi, yaitu Kabupaten Pacitan, Trenggalek, Lumajang, Situbondo, Bojonegoro, dan Tuban. Kondisi ini dianggap ideal dan dianggap sebagai kesuksesan program Keluarga Berencana.

Berikut ini adalah perbandingan nilai statistik mean, variansi, minimum, dan maksimum dari ketujuh variabel prediktor pada kategori wilayah yang belum mencapai target TFR (0) dan yang sudah mencapai target (1).

Tabel 2.

Deskriptif Variabel Prediktor pada Masing-Masing Kategori TFR

\begin{tabular}{ccccc}
\hline \hline Variabel & Y & Mean & Min & Max \\
\hline CPR (X1) & 0 & 64.47 & 52.60 & 73.92 \\
& 1 & 61.92 & 41.75 & 71.41 \\
Unmet Need (X2) & 0 & 9.089 & 4.78 & 13.21 \\
& 1 & 11.199 & 6.580 & 15.180 \\
UKP (X3) & 0 & 21.711 & 19.310 & 24.58 \\
Angka Kematian & 1 & 22.183 & 20.370 & 25.590 \\
Bayi (X4) & 1 & 27.92 & 16.05 & 56.24 \\
RLS Perempuan & 0 & 70.01 & 18.28 & 48.85 \\
(X5) & 1 & 7.530 & 4.08 & 10.83 \\
Informed Consent & 0 & 55.02 & 5.100 & 10.370 \\
(X6) & 1 & 64.44 & 7.49 & 98.93 \\
PDRB Perkapita & 0 & 30.26 & 15.69 & 89.86 \\
(X7) & 1 & 60.7 & 14.6 & 348.0 \\
Persentase PUS & 0 & 40.49 & 29.70 & 64.63 \\
(X8) & 1 & 37.49 & 25.57 & 45.47 \\
\hline \hline
\end{tabular}

Berdasarkan variabel Contraceptive Prevalence Rate $\left(\mathrm{X}_{1}\right)$, persentase unmet need $\left(\mathrm{X}_{2}\right)$, Usia Kawin Pertama $\left(\mathrm{X}_{3}\right)$, Angka Kematian Bayi $\left(\mathrm{X}_{4}\right)$, rata-rata lama sekolah perempuan $\left(\mathrm{X}_{5}\right)$, dan Informed Consent $\left(\mathrm{X}_{6}\right)$, nilai mean dan variansi antara wilayah yang belum mencapai target $(\mathrm{Y}=0)$ dengan wilayah yang sudah mencapai target $(Y=1)$ tidak jauh berbeda. Namun jika dilihat dari PDRB perkapita, kedua wilayah memiliki perbedaan dimana wilayah yang masuk kategori sudah mencapai target TFR memiliki nilai PDRB perkapita yang jauh lebih besar dibandingkan dengan wilayah yang belum mencapai target TFR. Hal ini menunjukkan bahwa masyarakat berpenghasilan tinggi cenderung untuk merencanakan jumlah anak yang lebih sedikit. Akan tetapi, variansi di kelompok 1 cukup besar sehingga memungkinkan terjadi kesenjangan pendapatan antar kabupaten/kota yang masuk kelompok 1.

\section{B. Pemodelan TFR di Jawa Timur}

Sebelum melakukan pemodelan, terlebih dahulu melakukan pendeteksian multikolinearitas, pembentukan model lengkap Regresi Logistik Biner, serta pembentukan model Regresi Logistik Biner dengan efek interaksi.

1. Pembentukan Model Regresi Logistik Biner

1.1 Deteksi Multikolinearitas

Asumsi multikolinearitas dideteksi dengan nilai VIF. Berikut adalah nilai VIF setiap variabel prediktor. 
Tabel 3.

Nilai VIF Variabel Prediktor

\begin{tabular}{ll}
\hline \hline Variabel Prediktor & Nilai VIF \\
\hline Contraceptive Prevalence Rate $\left(\mathrm{X}_{1}\right)$ & 2.210 \\
Persentase Unmet need $\left(\mathrm{X}_{2}\right)$ & 1.272 \\
Usia Kawin Pertama $\left(\mathrm{X}_{3}\right)$ & 6.683 \\
Angka kematian Bayi $\left(\mathrm{X}_{4}\right)$ & 3.061 \\
Rata-rata Lama Sekolah Perempuan $\left(\mathrm{X}_{5}\right)$ & 6.977 \\
Informed Consent $\left(\mathrm{X}_{6}\right)$ & 1.489 \\
PDRB Perkapita $\left(\mathrm{X}_{7}\right)$ & 1.680 \\
Persentase Pasangan Usia Subur $\left(\mathrm{X}_{8}\right)$ & 1.895 \\
\hline \hline
\end{tabular}

Berdasarkan Tabel 3, nilai VIF pada masing-masing variabel prediktor cenderung kecil, yaitu tidak lebih dari 10 . Hasil ini menjelaskan bahwa model tidak mengandung multikolinearitas atau tidak ada hubungan linier antar variabel prediktor. Untuk itu, kedelapan variabel dapat dimodelkan menggunakan Regresi Logistik.

1.2 Pengujian Signifikansi Parameter Serentak

Pada metode Regresi Logistik Biner, uji serentak dilakukan dengan Likelihood Ratio Test (G) yang ditunjukkan oleh tabel berikut.

Tabel 4.

\begin{tabular}{cccc}
\multicolumn{4}{c}{ Likelihood Ratio Test } \\
\hline \hline $\mathrm{G}$ & Chi-square & $\mathrm{df}$ & P-Value \\
\hline 29,170 & 13,362 & 8 & 0,000 \\
\hline \hline
\end{tabular}

Berdasarkan Tabel 4, diperoleh nilai G sebesar 29,170. Pada derajat bebas (df) 8 , didapatkan nilai Chi-square $\left(\chi_{8 ; 0,1}\right)$ sebesar 13,362. Statistik uji $\mathrm{G}$ memiliki nilai yang lebih besar dari nilai kritis 13,362 dan P-Value sebesar 0,000 lebih kecil dari taraf signifikansi $10 \%$. Untuk itu, pengujian diputuskan tolak $\mathrm{H}_{0}$ sehingga dapat disimpulkan bahwa minimal terdapat satu variabel yang memberikan pengaruh yang signifikan terhadap Total Fertility Rate (TFR).

\subsection{Pengujian Signifikansi Parameter Parsial}

Pengujian secara parsial dilakukan untuk mengetahui variabel-variabel yang memberikan pengaruh signifikan terhadap Total Fertility Rate (TFR).

Tabel 5.

Hasil Pengujian Parsial Model Regresi Logistik Biner

\begin{tabular}{lcc}
\hline \hline Prediktor & Wald & P-Value \\
\hline CPR $\left(\mathrm{X}_{1}\right)$ & 0,726 & 0,394 \\
Unmet Need $\left(\mathrm{X}_{2}\right)$ & 4,153 & $0,042^{* *}$ \\
UKP $\left(\mathrm{X}_{3}\right)$ & 0,448 & 0,503 \\
Angka Kematian bayi $\left(\mathrm{X}_{4}\right)$ & 2,023 & 0,155 \\
RLS Perempuan $\left(\mathrm{X}_{5}\right)$ & 3,176 & $0,075^{* *}$ \\
Informed consent $\left(\mathrm{X}_{6}\right)$ & 4,332 & $0,037^{* *}$ \\
PDRB Perkapita $\left(\mathrm{X}_{7}\right)$ & 3,840 & $0,050^{* *}$ \\
Persentase PUS $\left(\mathrm{X}_{8}\right)$ & 3,963 & $0,046^{* *}$ \\
\hline \hline
\end{tabular}

Untuk memperoleh variabel yang signifikan berpengaruh terhadap Total Fertilty Rate (TFR), statistik uji Wald pada ketujuh variabel harus lebih besar dari $\mathrm{Z}_{\alpha / 2}$, yaitu sebesar 1,645 atau p-value kurang dari 0,1. Berdasarkan Tabel 5, variabel yang memberikan pengaruh yang signifikan terhadap TFR adalah persentase unmet need $\left(\mathrm{X}_{2}\right)$, rata-rata lama sekolah perempuan $\left(\mathrm{X}_{5}\right)$, Informed Consent $\left(\mathrm{X}_{6}\right)$, PDRB Perkapita $\left(\mathrm{X}_{7}\right)$, dan persentase pasangan usia subur $\left(\mathrm{X}_{8}\right)$. 1.4 Model Terbaik Regresi Logistik
Pemilihan model terbaik Regresi Logistik Biner dilakukan dengan cara menyeleksi variabel menggunakan Backward selection. Prosedur ini dilakukan dengan mengeluarkan variabel yang memiliki p-value terbesar.

Tabel 6.

Pemodelan Regresi Logistik Hasil Seleksi Backward

\begin{tabular}{lcc}
\hline \hline Variabel & Wald & P-Value \\
\hline Unmet Need $\left(\mathrm{X}_{2}\right)$ & 6,666 & $0,010^{* *}$ \\
RLSPerempuan $\left(\mathrm{X}_{5}\right)$ & 5,093 & $0,024^{* *}$ \\
Informed consent $\left(\mathrm{X}_{6}\right)$ & 5,784 & $0,016^{* *}$ \\
PDRB Perkapita $\left(\mathrm{X}_{7}\right)$ & 5,013 & $0,025^{* *}$ \\
Persentase PUS $\left(\mathrm{X}_{8}\right)$ & 5,043 & $0,025^{* *}$ \\
\hline \hline
\end{tabular}

Hasil seleksi variabel menggunakan Backward menghasilkan lima variabel yang signifikan (p-value kurang dari 0,1). Kelima variabel tersebut adalah unmet need $\mathrm{KB}$, rata-rata lama sekolah perempuan, informed consent, PDRB Perkapita, serta persentase pasangan usia subur.

2. Pembentukan Model Lengkap Regresi Logistik dengan Efek Interaksi

2.1 Pembentukan Variabel Interaksi

Pada penelitian ini, terdapat dua metode untuk mengetahui ada tidaknya interaksi antar prediktor, yakni pembentukan interaksi variabel dengan menggunakan Moderated Multiple Regression (MMR). Metode Moderated Multiple Regression (MMR) diaplikasikan dengan cara memodelkan dua kali dengan regresi logit biner, yakni model dengan efek utama dan model dengan efek utama dan interaksi dari dua variabel yang diduga saling berinteraksi. Metode MMR juga dilakukan untuk seluruh kemungkinan interaksi yang terjadi antar variabel prediktor. Penelitian ini menggunakan delapan prediktor sehingga kemungkinan interaksi yang terjadi ada sebanyak ${ }_{2} \mathrm{C}_{8}$, yakni sebanyak 28 kombinasi interaksi variabel predikor.

Dari 28 kombinasi interaksi prediktor menggunakan MMR, diperoleh satu pasang variabel prediktor yang saling berinteraksi, yaitu informed consent $\left(\mathrm{X}_{6}\right)$ dan persentase Pasangan Usia Subur $\left(\mathrm{X}_{8}\right)$. Hasil MMR sebelum dan sesudah dilakukan pemodelan menggunakan interaksi ditampilkan pada Tabel 4.7 dan Tabel 4.8.

Tabel 7.

Hasil MMR Sebelum Dilakukan Interaksi $\mathrm{X}_{6,8}$

\begin{tabular}{ccc}
\hline \hline Prediktor & Wald & P-Value \\
\hline Constant & 0,825 & 0,364 \\
$\mathrm{X}_{6}$ & 1,818 & 0,178 \\
$\mathrm{X}_{8}$ & 2,155 & 0,142 \\
\hline \hline
\end{tabular}

Berdasarkan Tabel 6 di atas, variabel Persentase Pasangan Usia Subur $\left(\mathrm{X}_{8}\right)$ maupun Informed Consent $\left(\mathrm{X}_{6}\right)$ tidak memberikan pengaruh yang signifikan terhadap Total Fertility Rate (TFR). Selanjutnya, pemodelan dilakukan dengan menambahkan interaksi antar kedua variabel.

Tabel 8.

Hasil MMR Setelah Dilakukan Interaksi $\mathrm{X}_{6,8}$

\begin{tabular}{ccc}
\hline \hline Prediktor & Wald & P-Value \\
\hline Constant & 5,285 & 0,022 \\
$\mathrm{X}_{6}$ & 4,450 & $0,035^{* *}$ \\
$\mathrm{X}_{8}$ & 5,779 & $0,016^{* *}$ \\
$\mathrm{X}_{6} \mathrm{X}_{8}$ & 5,043 & $0,025^{* *}$ \\
\hline \hline
\end{tabular}


Nilai p-value yang diperoleh pada efek utama persentase Pasangan Usia Subur $\left(\mathrm{X}_{8}\right)$ dan Informed Consent $\left(\mathrm{X}_{6}\right)$, maupun interaksi keduanya kurang dari $10 \%$. Hal ini menunjukkan baik efek utama maupun interaksi variabel tersebut memberikan pengaruh yang signifikan terhadap Angka fertilitas total.

Variabel persentase Pasangan Usia Subur $\left(\mathrm{X}_{8}\right)$ diduga mempengaruhi hubungan langsung antara Informed Consent $\left(\mathrm{X}_{6}\right)$ dengan Angka fertilitas total $(\mathrm{Y})$ atau dengan kata lain $\mathrm{X}_{8}$ diduga sebagai variabel moderator. Informed consent dan pasangan usia subur dianggap sebagai salah satu faktor yang mempengaruhi fertilitas. Informed consent harus ditandatangani oleh pasangan suami istri yang menyatakan persetujuan mereka melakukan $\mathrm{KB}$ [13]. Informed consent akan tinggi jika pasangan usia subur semakin banyak. Informed consent yang tinggi di suatu wilayah akan mempengaruhi tingkat fertilitas di wilayah tersebut.

2.2 Pengujian Signifikansi Parameter Serentak

Uji serentak dilakukan dengan Likelihood Ratio Test (G) yang ditunjukkan oleh tabel berikut.

Tabel 9.

\begin{tabular}{cccc}
\multicolumn{4}{c}{ Likelihood Ratio Test } \\
\hline \hline $\mathrm{G}$ & Chi-square & df & P-Value \\
\hline 33,655 & 14,684 & 9 & 0,000 \\
\hline \hline
\end{tabular}

Berdasarkan Tabel 4.12, diperoleh nilai G sebesar 33,655. Pada derajat bebas (df) 9 , didapatkan nilai Chi-square $\left(\chi_{9 ; 0,1}\right)$ sebesar 14,684. Untuk itu, pengujian diputuskan tolak $\mathrm{H}_{0}$ sehingga dapat disimpulkan bahwa minimal terdapat satu variabel yang memberikan pengaruh yang signifikan terhadap Total Fertility Rate (TFR).

2.3 Pengujian Signifikansi Parameter Parsial

Langkah berikutnya adalah melakukan pengujian parsial pada model Regresi Logistik yang melibatkan efek utama dari kedelapan variabel dan interaksi $\mathrm{X}_{6}$ dan $\mathrm{X}_{8}$.

Tabel 10.

Uji Parsial Model Lengkap Efek Utama dengan Efek Interaksi X 68

\begin{tabular}{lcc}
\hline \multicolumn{1}{c}{ Prediktor } & Wald & P-Value \\
\hline CPR $\left(\mathrm{X}_{1}\right)$ & 0,632 & 0,426 \\
Unmet Need $\left(\mathrm{X}_{2}\right)$ & 2,803 & $0,094 * *$ \\
$\mathrm{UKP}\left(\mathrm{X}_{3}\right)$ & 0,041 & 0,839 \\
$\mathrm{AKB}\left(\mathrm{X}_{4}\right)$ & 2,237 & 0,135 \\
RLS Perempuan $\left(\mathrm{X}_{5}\right)$ & 2,119 & 0,146 \\
Informed consent $\left(\mathrm{X}_{6}\right)$ & 2,656 & 0,103 \\
PDRB Perkapita $\left(\mathrm{X}_{7}\right)$ & 2,338 & 0,126 \\
Persentase PUS $\left(\mathrm{X}_{8}\right)$ & 3,700 & $0,054^{* *}$ \\
$\mathrm{X}_{6} \mathrm{X}_{8}$ & 3,433 & $0,064 * *$ \\
\hline \hline
\end{tabular}

Berdasarkan hasil uji parsial model lengkap efek utama dengan interaksi $\mathrm{X}_{6,8}$, diperoleh tiga variabel yang memiliki pvalue kurang dari 0,1 . Ketiga variabel itu adalah persentase unmet need, persentase pasangan usia subur, dan interaksi antara informed consent dan persentase pasangan usia subur $\left(\mathrm{X}_{6,8}\right)$. Jika dibandingkan dengan hasil pemodelan pada Tabel 5 , penambahan interaksi $\mathrm{X}_{6,8}$ menyebabkan variabel yang signifikan berkurang.

2.4 Model Terbaik Regresi Logistik dengan Efek Interaksi

Pemilihan model terbaik dilakukan dengan cara menyeleksi variabel menggunakan Backward selection.
Tabel 11.

pemodelan Regresi Logistik dengan Efek Interaksi Hasil Seleksi Backward

\begin{tabular}{lrr}
\hline \hline \multicolumn{1}{c}{ Prediktor } & \multicolumn{1}{c}{ Wald } & \multicolumn{1}{c}{ P-Value } \\
\hline Unmet Need $\left(\mathrm{X}_{2}\right)$ & 6,477 & 0,011 \\
RLS Perempuan $\left(\mathrm{X}_{5}\right)$ & 4,625 & 0,032 \\
Informed consent $\left(\mathrm{X}_{6}\right)$ & 3,182 & 0,074 \\
PDRB Perkapita $\left(\mathrm{X}_{7}\right)$ & 3,889 & 0,049 \\
Persentase PUS $\left(\mathrm{X}_{8}\right)$ & 5,689 & 0,017 \\
$\mathrm{X}_{6} \mathrm{X}_{8}$ & 4,139 & 0,042 \\
Constant & 4,843 & 0,028 \\
\hline \hline
\end{tabular}

Hasil pemodelan menggunakan Backward menghasilkan enam variabel yang signifikan karena p-value lebih besar dari 0,1 . Efek utama dan interaksi memberikan pengaruh terhadap model. Dengan demikian, persentase unmet need, rata-rata lama sekolah perempuan, informed consent, PDRB Perkapita, persentase pasangan usia subur, serta interaksi antara informed consent dan PDRB perkapita memberikan pengaruh terhadap Angka fertilitas total pada tingkat kepercayaan $90 \%$.

3. Evaluasi Ketepatan Klasifikasi

Selanjutnya, ingin diketahui apakah penambahan interaksi lebih baik atau tidak, dapat dilihat melalui akurasi ketepatan klasifikasi. Berikut adalah perbandingan ketepatan klasifikasi model Regresi Logistik tanpa interaksi dan dengan interaksi.

Tabel 12.

\begin{tabular}{cc} 
Perbandingan Akurasi Model Tanpa dan dengan Efek Interaksi \\
\hline \hline Metode Regresi Logistik & Akurasi \\
\hline Dengan Interaksi & $92,1 \%$ \\
Tanpa interaksi & $86,8 \%$ \\
\hline
\end{tabular}

Hasil akurasi atau ketepatan klasifikasi dari model Regresi Logistik Biner dengan efek interaksi lebih besar dibandingkan model tanpa interaksi. Ketepatan klasifikasi model dengan interaksi adalah sebesar $92,1 \%$ sedangkan model tanpa interaksi sebesar $86,8 \%$. Hasil ini menunjukkan bahwa keberadaan interaksi variabel mampu meningkatkan ketepatan klasifikasi untuk memodelkan Angka fertilitas total di Jawa Timur. Oleh sebab itu, Angka fertilitas total lebih baik dimodelkan menggunakan Regresi Logistik dengan efek interaksi.

4. Uji kesesuaian Model

Nilai statistik uji Deviasi sebesar 18,603. Pada derajat bebas 31 didapatkan nilai kritis Chi-square $\left(\chi_{21 ; 0,1}\right)$ sebesar 41,42 lebih besar dari statistik uji Deviasi. Hasil ini juga didukung dengan p-value sebesar 0,961 lebih dari taraf signifikansi $10 \%$ sehingga diputuskan gagal tolak $\mathrm{H}_{0}$. Dengan demikian, pada tingkat kepercayaan 90\% dapat disimpulkan bahwa hasil prediksi model telah sesuai dan tidak ada perbedaan yang signifikan antara hasil prediksi pemodelan dengan data hasil observasi.

5. Interpretasi Model Regresi Logistik dengan Efek Interaksi

Model terbaik untuk Total Fertility Rate (TFR) kabupaten/kota di Jawa Timur menggunakan Regresi Logistik Biner dengan efek interaksi ditampilkan pada persamaan 4.1:

$$
\pi_{i} x_{i}=\frac{\exp \left(\mathbf{x}_{i} \hat{\boldsymbol{\beta}}\right)}{1+\exp \left(\mathbf{x}_{i} \hat{\boldsymbol{\beta}}\right)}
$$


dimana:

$$
\mathbf{x} \hat{\boldsymbol{\beta}}=44.103+1.202 X_{2}-2.111 X_{s}-0.454 X_{6}+0.179 X_{q}-1.421 X_{s}+0.015 X_{6, s}
$$

Interpretasi dari model regresi logistik biner dengan efek interaksi tidak berdasarkan nilai koefisien $\beta$ melainkan menggunakan Odds Ratio (OR). Nilai OR digunakan untuk mengetahui kecenderungan masing-masing variabel prediktor terhadap Total Fertility Rate (TFR) untuk setiap kabupaten/kota di Jawa Timur.

Tabel 13.

Odds Ratio Hasil Model Lengkap Regresi Logistik Biner dengan Efek Interaksi

\begin{tabular}{|c|c|c|c|}
\hline Prediktor & $\beta$ & $\mathrm{OR}=\operatorname{Exp}(\beta)$ & $1 / \mathrm{OR}$ \\
\hline Unmet Need $\left(\mathrm{X}_{2}\right)$ & 1.202 & 3,327 & 0,300 \\
\hline RLS Perempuan (X $\left.\mathrm{X}_{5}\right)$ & $-2,111$ & 0,121 & 8,264 \\
\hline Informed consent $\left(\mathrm{X}_{6}\right)$ & $-0,454$ & 0,103 & 9,679 \\
\hline PDRB Perkapita $\left(\mathrm{X}_{7}\right)$ & 0,179 & 1,196 & 0,836 \\
\hline Persentase PUS $\left(\mathrm{X}_{8}\right)$ & $-1,421$ & 0,241 & 4,149 \\
\hline $\mathrm{X}_{6} \mathrm{X}_{8}$ & 0.015 & 1,162 & 0,150 \\
\hline
\end{tabular}

Berdasarkan Tabel 13, akan diberikan contoh untuk menginterpretasikan nilai OR. Nilai Odds Ratio sebesar 3,327 menunjukkan bahwa setiap kenaikan satu persen unmet need, maka peluang suatu kabupaten/kota untuk masuk kelompok di bawah target Angka fertilitas total adalah sebesar 3,327 kali lipat. Nilai Odds Ratio sebesar 8,26 menunjukkan bahwa setiap kenaikan satu angka rata-rata lama sekolah perempuan, maka peluang suatu kabupaten/kota di Jawa Timur untuk masuk kelompok di atas target adalah sebesar 8,26 kali lipat. OR sebesar 1,162 menunjukkan bahwa kenaikan sepuluh persen informed consent yang dibarengi dengan kenaikan sepuluh persen pasangan usia subur memberikan peluang suatu kabupaten/kota di Jawa Timur untuk masuk kelompok di bawah target sebesar 1,162 kali lipat. Variabel yang memberikan pengaruh paling besar terhadap Angka fertilitas total adalah kenaikan satu angka rata-rata lama pendidikan perempuan.

\section{Pemetaan Total Fertility Rate (TFR) di Jawa Timur}

Selanjutnya, dilakukan pemetaan untuk mengetahui hasil klasifikasi Angka fertilitas total (TFR) sebelum dilakukan pemodelan (aktual) dan sesudah dilakukan pemodelan Regresi Logistik dengan efek interaksi. Pemetaan TFR kabupaten/kota di Jawa Timur ditampilkan pada Gambar 3 dan Gambar 4.

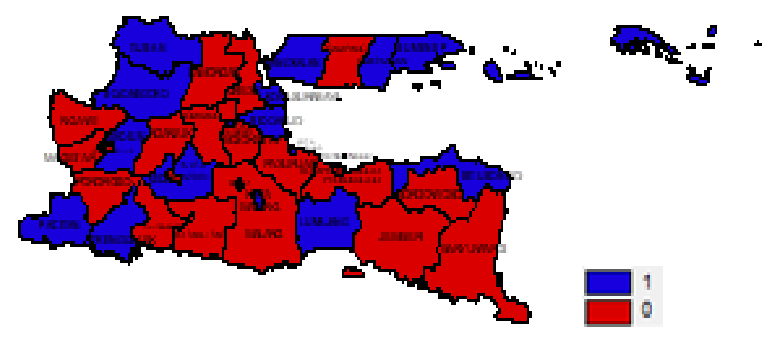

Gambar 3. Pemetaan TFR Sebelum Pemodelan.

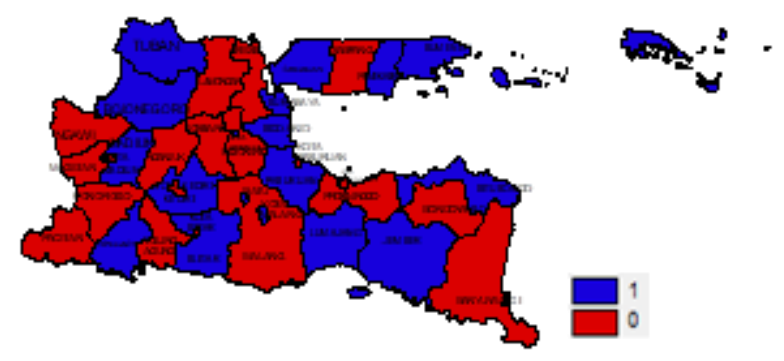

Gambar 4. Pemetaan TFR Hasil Pemodelan Regresi Logistik dengan Efek Interaksi.

Kabupaten/kota yang tergolong dalam kategori TFR telah mencapai target ditunjukkan oleh area berwarna biru. Kabupaten/kota yang belum mencapai target ditunjukkan oleh area berwarna merah. Secara umum, klasifikasi TFR kabupaten/kota di Jawa Timur dengan menggunakan data aktual tidak jauh berbeda dengan hasil prediksi model terbaik Regresi Logistik Biner dengan efek interaksi. Perbedaannya, jika pada data aktual Kabupaten Pacitan tergolong ke dalam kategori TFR mencapai target, maka hasil pemodelan mengklasifikasikan ke dalam kategori TFR belum mencapai target. Begitupun pada kabupaten Jember dan Kabupaten Blitar yang awalnya tergolong TFR belum mencapai target, pada hasil pemodelan keduanya masuk kategori TFR telah mencapai target. Ini menunjukkan bahwa pemodelan Regresi Logistik dengan efek interaksi mampu mengklasifikasikan TFR kabupaten/kota di Jawa Timur dengan baik.

\section{KESIMPULAN DAN SARAN}

Berikut ini merupakan kesimpulan yang dapat diberikan dari hasil analisis dan pembahasan.

1. Perbandingan antara wilayah yang belum dan mencapai target TFR yang ditetapkan BKKBN cukup seimbang. Rata-rata angka prevalensi $\mathrm{KB}$, persentase unmet need $\left(\mathrm{X}_{2}\right)$, Usia Kawin Pertama, Angka Kematian Bayi, rata-rata lama sekolah perempuan, dan Informed Consent antara wilayah yang belum mencapai target TFR dengan wilayah yang sudah mencapai target TFR tidak jauh berbeda. Namun jika dilihat dari PDRB perkapita, kedua wilayah memiliki perbedaan dimana wilayah yang masuk kategori sudah mencapai target TFR memiliki nilai PDRB perkapita yang jauh lebih besar dibandingkan dengan wilayah yang belum mencapai target TFR.

2. Hasil pemodelan Angka fertilitas total menggunakan Regresi Logistik Biner dengan efek interaksi memberikan informasi bahwa persentase unmet need, rata-rata lama sekolah perempuan, informed consent, PDRB Perkapita, persentase pasangan usia subur, serta interaksi antara informed consent dan PDRB perkapita memberikan pengaruh yang signifikan terhadap Angka fertilitas total. Model terbaik Total Fertility Rate (TFR) kabupaten/kota 
di Jawa Timur menggunakan Regresi Logistik Biner dengan efek interaksi:

$$
\pi_{i}\left(x_{i}\right)=\frac{\exp \left(44.103+1.202 X_{2}-2.111 X_{5}-0.454 X_{6}+0.179 X_{7}-1.421 X_{8}+0.015 X_{6,8}\right)}{1+\exp \left(44.103+1.202 X_{2}-2.111 X_{5}-0.454 X_{6}+0.179 X_{7}-1.421 X_{8}+0.015 X_{6,8}\right)}
$$

3. Pemodelan Angka fertilitas total menggunakan Regresi Logistik Biner dengan efek interaksi mampu mengklasifikasikan kabupaten/kota ke dalam kategori belum dan sudah mencapai target TFR sebesar 92,1\% dengan misklasifikasi hanya $7,9 \%$.

Saran yang dapat diberikan adalah perlunya mengevaluasi program KB khsusunya di wilayah yang memiliki angka prevalensi KB yang rendah sedangnya angka fertilitasnya tinggi. Selain itu, Pemerintah perlu bersikap tegas dalam memberikan izin bagi masyarakat yang ingin menikah di bawah umur. Pendidikan penduduk perempuan juga patut menjadi fokus utama untuk ditingkatnya. Pemerintah dapat mengadakan pelatihan dan penyuluhan keluarga berencana khususnya kepada penduduk usia muda.

\section{DAFTAR PUSTAKA}

[1] K. Ladimar, "Analisis Tingkat Fertilitas di Kabupaten/Kota Provinsi Jawa Timur," Semarang, 2016.

[2] F. Isnaini, "Pemodelan Kasus Diabetes Mellitus Tipe 2 di Klinik Assalaam Kabupaten Banjarnegara Jawa Tengah dengan Metode Probit Biner," Surabaya, 2017.

[3] J. Li, J. Weng, C. Shao, and H. Guo, "Cluster-Based Logistic Regression Model for Holiday Travel Mode Choice," in Procedia Engineering, 2016, pp. 729-737.

[4] Setiawan and Dwi Endah Kusrini, Ekonometrika. Andi, 2010.

[5] A. Agresti, Categorical Data Analysis, 2nd ed. New York: John Wiley \& Sons, Inc, 2002.

[6] D. Hosmer and J. Lemeshow, Applied Logistic Regression, 2nd ed. USA: John Wiley \& Sons Inc, 2000

[7] U. Sekaran, Metodologi Penelitian untuk Bisnis, 4th ed. Jakarta: Salemba Empat, 2007.

[8] J. Jaccard, Interaction Effects in Logistic Regression. USA: SAGE Publications, Inc, 2001.

[9] Y. Rahma, "Analisis Tingkat Partisipasi Perempuan dalam Angkatan Kerja di Provinsi Jawa Timur Menggunakan Regresi Probit Biner dengan Efek Interaksi," Institut Teknologi Sepuluh Nopember, 2017.

[10] R. Johnson and D. Wichern, Applied Multivariate Statistikal Analysis, 6th ed. USA: Pearson Education, Inc, 2007.

[11] J. Han, M. Kamber, and J. Pei, Data Mining Concepts and Techniques. Morgan Kaufman Publisher, 2012.

[12] Mantra, Demografi Umum. Yogyakarta: Pustaka Pelajar, 2007. 